${ }^{1}$ Department of Cosmetology, Faculty of Pharmaceutical Sciences in Sosnowiec, Medical University of Silesia, Kasztanowa Street 3, 41-200 Sosnowiec

\title{
Post-treatment physiological effects, adverse effects and complications after the selected aesthetic treatments. Review of the literature
}

\author{
Fizjologiczne skutki pozabiegowe, dzialania niepożadane \\ oraz powiklania po wybranych zabiegach estetycznych. Przeglad literatury
}

\begin{abstract}
Aesthetic treatments are performed in order to improve physical attractiveness, well-being, and to eliminate skin defects. These procedures are also associated with physiological post-treatment effects, side effects and complications.

The aim of the article was to discuss selected aesthetic treatments with their typical complications and to present the types of natural post-treatment effects and dangerous side effects.

Knowledge of the causes and occurrence of undesirable effects after various aesthetic treatments allows to increase awareness of the risks associated with the performance of such procedures.
\end{abstract}

Keywords: complications, side effects, postoperative effects, aesthetic treatments, cosmetology, aesthetic medicine

\section{STRESZCZENIE}

Zabiegi estetyczne wykonywane są w celu poprawy samopoczucia, atrakcyjności fizycznej oraz niwelowania defektów skórnych. Procedury zabiegowe wiążą się także z fizjologicznymi skutkami pozabiegowymi, działaniami niepożądanymi oraz powikłaniami.

Celem artykułu było omówienie wybranych zabiegów estetycznych wraz z charakterystycznymi dla nich powikłaniami oraz przedstawienie rodzajów naturalnych skutków pozabiegowych i niebezpiecznych działań niepożądanych.

Znajomość przyczyn i występowania skutków niepożądanych po różnych zabiegach estetycznych, pozwalają na zwiększenie świadomości zagrożeń związanych z wykonywaniem usług w tym zakresie.

Słowa kluczowe: powikłania, działania niepożądane, skutki pozabiegowe, zabiegi estetyczne, kosmetologia, medycyna estetyczna

\section{INTRODUCTION}

Cosmetology deals with caring, restoring and increasing the physical attractiveness of the human body with the use of methods such as cosmetic products, supplements, dietary interventions, rehabilitation and care treatments (non-invasive) or slightly invasive [1]. It is an interdisciplinary field, combining knowledge in the fields of biological, chemical, health and physical culture sciences as well as medical sciences, in particular related to the issues of dermatology and aesthetic medicine [2].

Aesthetic medicine is related to dermatology and aesthetic surgery. It includes invasive and non-invasive procedures aimed at improving the patient's physical aesthetics as well as procedures reserved exclusively for doctors with a license to practice, such as prescription of pharma- 
cological agents (registered as medicinal products) which can only be obtained with a prescription [3].

The aim of aesthetic treatments is to improve, restore and create physical attractiveness, including prevention, delaying aging processes, skin care and beautification, and correction of skin defects on various grounds that do not require hospitalization [4]. The selected aesthetic treatments include: chemical peelings, needle mesotherapy, carboxytherapy, cryolipolysis, HIFU technology and a plasma generator.

The popularity of these treatments is gradually increasing, mainly due to the desire to improve physical attractiveness and well-being. The increase in the number of surgical procedures is also associated with the occurrence of postoperative complications, which, despite taking special precautions, are inevitable.

The article focuses on the causes of side effects, presents the physiological reactions after the procedures and the most common complications after selected aesthetic procedures.

\section{SELECTED AESTHETIC TREATMENTS}

- Chemical peelings are widely used in cosmetology and aesthetic medicine. These products contain one or more chemical compounds in a specific concentration, which accelerate cell renewal, skin exfoliation and regeneration. There are several of peelings depending on the depth of penetration and intended use. The procedure involves the application of a chemical substance with a brush, cotton swab or sterile gauze on the surface of previously degreased skin [5].

- Needle mesotherapy is a method involving the intradermal administration of small doses of active or medicinal substances. The treatment aims to improve the condition and appearance of the skin by stimulating the production of collagen by fibroblasts as a result of an injection itself. Preparations used during the procedure help in solving aesthetic problems such as skin aging, skin defects or alopecia [6]. Products for needle mesotherapy must be sterile, have a certificate confirming the intended use and information about the possibility of using a given product by qualified cosmetologists or doctors. Mesotherapy preparations may contain one, two or more active ingredients (commonly referred to as "cocktails") [7].

- Carboxytherapy is a method of a wide and effective application in cosmetology and aesthetic medicine. It is a procedure involving the administration of intradermal or subcutaneous injection of medical carbon dioxide [8]. Carboxytherapy is used especially in the revitalization of the facial skin, smoothing wrinkles, eliminating dark circles under the eyes, reducing scars, stretch marks, cellulite and adipose tissue [9].
- Cryolipolysis is a non-invasive method of removing excessive and unwanted fatty tissue from selected areas of the human body. The treatment involves acting by controlled low temperature on adipocytes in order to lipolyze them. Cryolipolysis is performed with the use of specialized equipment with a head that sucks the skin fold together with the fatty tissue into the chamber with cooling elements [10].

- HIFU (High Intensity Focused Ultrasound) technology uses a concentrated beam of high-frequency ultrasound. An ultrasonic wave is sent from the head, forming a cone, at the end of which energy is concentrated. It heats the tissues to a temperature of about $65-70^{\circ} \mathrm{C}$. The treatment is performed with an ultrasound gel and a head with replaceable cartridges with different penetration depths, thanks to which it is possible to adjust the technology in the appropriate treatment area. In cosmetology and aesthetic medicine, HIFU is used to eliminate wrinkles, improve skin elasticity and firmness, and reduce excess of fat tissue [11].

- Plasma generators create a controlled and targeted plasma micro beam by ionizing the gases in the air. The generated plasma creates a small electric arc between the tip of the device and the skin of the client, causing the sublimation of the epidermis and contraction of the skin in a controlled manner. It does not cause bleeding, inflammation or necrosis of the surrounding tissues of the treatment area, because the plasma action focuses on the border from the basal layer to the dermis [12]. Plasma treatment is used to reduce wrinkles and skin laxity - most often as a non-surgical substitute for eyelid blepharoplasty [13].

\section{PHYSIOLOGICAL POST-TREATMENT REACTION, ADVERSE EFFECTS AND COMPLICATION}

\section{Postoperative physiological reaction}

The post-treatment physiological reaction is an inevitable reaction of the body to the mechanical, physical or chemical factor of a given method. It occurs in the case of cosmetological procedures, which may cause symptoms lasting several days such as "flaky" exfoliation of the skin. Due to the long period of convalescence, clients subjected to such procedures should be under the constant supervision of the person performing the procedure and obligatory follow rules of post-treatment process in order to prevent further complications.

\section{Adverse reaction}

An adverse effect is a harmful and unintended reaction to the mechanical, physical or chemical factor of a given aesthetic treatment despite the use of correct treatment pro- 
cedures, special precautions, proper hygiene and the rules of post-treatment procedure. Unlike the physiological post-treatment reaction, side effects are an unexpected reaction during or after the procedure. If the abnormality is noticed quickly during the procedure or reported to the person performing the procedure, it will be possible to control the unwanted post-treatment reaction by consulting and introducing appropriate treatment by a doctor or changing the already existing rules in post-treatment proceedings.

\section{Complications}

Complications are most often result of improper treatment, an incorrectly performed cosmetological treatment or inappropriate post-treatment procedure. Frequently a complication depends on the specificity of a particular organism, a given preparation, or its cause is unknown or impossible to determine. In contrast to physiological post-treatment reactions, complications may leave unsightly damage to the skin in the form of discoloration, atrophic or hypertrophic scars, etc., which are often dif- ficult to reverse, and may be dangerous to health, sometimes life-threatening, requiring advanced treatment and medical intervention.

The causes of post-treatment complications may depend both on the person performing the procedure and the person undergoing the procedure, or resulting from the specifics of the preparation or treatment procedure.

\section{CHARACTERISTICS OF SELECTED PHYSIOLOGICAL POST-TREATMENT REACTIONS}

\section{Pain and burning sensation}

The intensity of pain and burning, depending on the individual feelings of the client, ranges from mild to intense. It is the result of the body's physiological response to the chemical, physical or mechanical action of a given cosmetological procedure. It may be short-term, which disappears after a few hours after the procedure, and long-term and to a greater extent, lasting for several hours after the procedure [14].

Table 1 Division of the causes of side effects and postoperative complications

\begin{tabular}{|c|c|}
\hline & CAUSES OF ADVERSE EFFECTS AND POST-TREATMENT COMPLICATIONS \\
\hline \multirow{13}{*}{$\begin{array}{l}\text { Depending on the person } \\
\text { performing the procedure }\end{array}$} & lack of appropriate education of the person performing the procedure \\
\hline & completing incorrect training \\
\hline & error in the course of the procedure \\
\hline & lack of hygiene and sterility during the procedure \\
\hline & lack of suitable conditions in which the treatment is carried out (e.g. at home, close to pets) \\
\hline & client is not qualified for the procedure \\
\hline & conducting an inaccurate health interview \\
\hline & ignoring signals from the client regarding his health and well-being during and after the procedure \\
\hline & prioritizing financial benefits over safety \\
\hline & selection of a preparation from an unknown source \\
\hline & choosing the wrong preparation (not in accordance with the intended use) \\
\hline & the use of faulty and low-quality equipment for the procedure \\
\hline & failure to inform the client about the post-treatment proceedings \\
\hline $\begin{array}{l}\text { Depending on the } \\
\text { cosmetic product used } \\
\text { during the procedure }\end{array}$ & hypersensitivity or allergy of the client to the preparation used during the treatment \\
\hline & failure to provide / conceal important information about the state of health before the procedure \\
\hline undergoing & failure to follow the hygiene rules after the procedure \\
\hline & using improper post-treatment care \\
\hline
\end{tabular}

Source: Own study based on [5] 


\section{Erythema}

Erythema is the result of vasodilation, which is manifested by reddening of part or all of the treatment area or may be in the form of single red spots. In most cases, erythema is an expected side effect (because it results from the induction of controlled inflammation, which is a physiological reaction of the body after the procedure), however, if the redness persists for more than 48 hours, it will require consultation with a doctor together with the person performing the procedure [14].

\section{Swelling and edema}

Edema is the accumulation of serous, purulent or mixed fluid in the extracellular space resulting from inflammation or an allergic reaction $[15,16]$. It is usually mild and resolves spontaneously or under the influence of treatment initiated by a doctor within 24-72 hours after the procedure. This is due to allergic reactions or the consequences of treatments that intention causes irritating effect or the skin breaks. The swelling may also be very intense and last for several days or be so severe that it makes it impossible to open the eyes - in such situations, medical consultation is required [17].

\section{Itching}

Itching may appear during the procedure and long after its completion as a result of an allergic reaction and during the peeling of the epidermis and healing of the skin. The itch associated with the healing process may be troublesome for the client, therefore in such case it requires medical consultation due to the necessity to prescribe oral or external histamine medications in the form of ointments and creams. The intensification of itching with accompanying erythema and small pustules may also indicate an allergy to a component of the preparation used in post-treatment care [18].

\section{CHARACTERISTICS OF SELECTED ADVERSE EFFECTS}

\begin{abstract}
Allergic reaction
An allergic reaction is a complex response of immune system to contact with a sensitizing agent. It varies in severity it may cause swelling, erythema and skin rash or begin with coughing and itching, then progress to respiratory or circulatory failure, and even death. Symptoms may appear immediately after contact with an allergen or be delayed [14].
\end{abstract}

\section{Reactivation of HSV herpes symptoms}

Active herpes is a contraindication to the procedure, regardless of whether the herpes lesions are in the treatment area or not, because the herpes simplex virus (in Latin herpes simplex virus) affects the entire body. Performing the procedure in its active period will result in the spread of changes to a severe degree, which may also infect other organs within the face (e.g. eyes).

\section{Demarcation lines}

The demarcation line is characterized by a line of pigmentation changes creating a clear difference between the border of the area subjected to a given treatment and the border of the skin of the non-treated area [20].

\section{CHARACTERISTICS OF SELECTED COMPLICATIONS}

\section{Bacterial, yeast and biofilm infection}

There is a great risk of infection with microorganisms during the procedures. It happens when the procedures are performed in inappropriate conditions, when make-up removal is not performed properly, the treatment area is not disinfected, and when sterile tools are not used during the procedure [18]. Infection may also occur as a result of inadequate post-treatment care, e.g. the use of occlusive preparations (containing fat, petroleum jelly) and moisturizing substances that favor the growth of potential pathogens and the lack of hygiene of the client. The most frequently reported infections are Staphylococcus, Streptococcus, Pseudomonas bacteria and Candida yeasts. Infections are manifested by redness, swelling, pain, increased heat at the treatment site, fever and skin eruptions [19].

If not properly treated, a bacterial infection causes bacteria to build up a biofilm. Biofilms are characterized by a reduced metabolism that produces resistance to antibiotics, and genetic differentiation that protects against the human immune system, contributing to chronic, difficult-to-treat infection [18].

\section{Discoloration}

Discoloration is limited changes with a different color than the rest of the skin. The causes of discoloration are chemical, mechanical and physical injuries as a result of a given aesthetic treatment, failure to use creams with a UV filter after the treatment or excessive exposure to the sun shortly after the treatment [20].

\section{Scars}

A scar is a skin change resulting from a repair process that is the body's reaction to an injury - a break in the continuity of the skin. Atrophic scars are formed in the process of abnormal healing with reduced collagen production. The fibrous connective tissue does not fill the entire tissue defect caused by acute inflammation, leaving small cavities in the skin. Hypertrophic scars result from an abnormal wound healing process. They are characterized by scarred, hard and convex tissue overgrowth above the skin surface of various sizes and shapes [21]. 
The reasons for the formation of scars after aesthetic treatments include inadequate or aggressive work of the person performing the treatment, inadequate care or non-compliance with post-treatment rules by the client.

\section{Epidermolysis}

Epidermolysis is a blistering separation of the epidermis due to the action of a strong and deeply penetrating substance used during the procedure [22].

\section{CHARACTERISTIC POST-TREATMENT REACTIONS, ADVERSE EFFECTS AND COMPLICATIONS OF SELECTED AESTHETIC PROCEDURES}

\section{Chemical peelings}

Chemical peelings carry a risk of side effects such as: secondary infection, demarcation lines, acne rash, ecchymosis and telangiectasia. Complications that can occur after chemical substances are scarring, sensory disturbances, changes in the skin structure, pigment disorders and epidermolysis. The ingredients of some chemical peelings, such as resorcinol or salicylic acid, can cause poisoning. All chemicals are dangerous to the eyes, so special caution during the procedure must be maintained, because accidentally introducing a few drops of acid into the conjunctival sac may cause eye burns characterized by severe redness of the eye, dryness, a feeling of sand or hair in the eye, and irreversible damage. On the other hand, the physiological reaction of selected chemical peeling will be frost, which is manifested by long-term, flaky skin peeling accompanied by itching, as well as skin inflammation with erythema, and acne lesions [19, 22-24].

\section{Needle mesotherapy}

Physiological post-treatment reactions after needle mesotherapy are pain of varying intensity, redness and swelling. Characteristic side effects in needle mesotherapy are slight scratch marks, skin exfoliation, skin infections, discoloration and an allergic reaction to a product component administered with the needle mesotherapy. It is usually characterized by prolonged redness and swelling, requiring pharmacological treatment prescribed by a physician. A dangerous reaction to an allergen that may occur during the procedure is anaphylactic shock, which is results in an ambulance call, doctor's intervention and first aid by a cosmetologist. Complications after needle mesotherapy also include discoloration resulting from unauthorized sun exposure [25-27].

\section{Carboxytherapy}

Crepitations are the result of the injection of carbon dioxide in the treatment area. They manifest as a feeling of bloat- ing and an increase in the volume of tissues are noticeable, which persist even several hours after the treatment and are among the natural post-treatment symptoms. Side effects of carboxytherapy are swelling that lasts up to 4 days and hematomas, which are subcutaneous haemorrhages that indicate vascular damage due to needle insertion. Swelling and bruising are not considered serious complications, but due to the unsightly appearance, clients often abandon facial carboxytherapy. Although carboxytherapy is a relatively safe procedure, it may lead to complications in the form of damage to the vagus nerve [28].

\section{Cryolipolysis}

Complications after cryolipolysis procedure are rather rare. They usually occur as a result of the use of low-quality equipment, poor selection of parameters or the lack of a special anti-frost membrane. In such cases, there is a risk of frostbite of the skin, often accompanied by blisters, which result in scarring and discoloration. On the other hand, the body's physiological response to the cryolipolysis procedure is local redness and swelling of the skin [23].

\section{HIFU technology}

Devices using HIFU technology cause a natural post-treatment reaction in the form of erythema and swelling of varying intensity, which disappear within a few hours or even days. Side effects of this treatment are long-lasting pain after the procedure, bruises, lumps in the subcutaneous tissue, a burning sensation and hives. Complications include burns, which can cause blisters and scabs, and usually end in scarring and discoloration. A very serious complication after inappropriate HIFU procedure is nerve paralysis, superficial sensory disturbance, bone burn and necrosis [29, 30].

\section{Plasma generators}

The characteristic side effects of the plasma generator are scabs, reddening of the skin and often quite troublesome swelling, lasting for about 2-3 days. Risky complications of this procedure include discoloration, scars resulting from the tearing of post-treatment scabs and infections due to improper care after the procedure [31].

\section{SUMMARY}

Aesthetic procedures are aimed at improving the appearance and condition of the skin and eliminating skin defects. However, it should be borne in mind that aesthetic procedures are associated not only with physiological postoperative reactions or side effects, but sometimes also with serious complications, which, despite taking special precautions, are inevitable. The knowledge of their reasons and increasing awareness of the risks associated with the provision of methods in this area, also arouses the need for continuous education of specialists in order to provide treat- 
ment services at a high level and appropriate qualification for the procedure. Sometimes a medical qualification is also necessary.

In view of the above, it should be remembered that even serious complications may not be directly life-threatening if they are promptly reported to the doctor and the person performing the procedure.

\section{REFERENCES / LITERATURA}

1. Śpiewak R. Kosmetologia. Dermatopedia. 2013;2(pl):002. https://doi.org/10.14320/dermatopedia.pl.2013.002

2. Polska Kosmetologia i Kosmetyka. https://pkik24.pl/warto-wiedziec/ kosmetologia-i-medycyna-estetyczna-synergia. Accessed 09.11.2020.

3. Śpiewak R. Estetologia medyczna, medycyna estetyczna, dermatologia estetyczna, chirurgia estetyczna, ginekologia estetyczna, stomatologia estetyczna - definicje i wzajemne relacje poszczególnych dziedzin. Estetol Med Kosmetol. 2012;2(3):69-71.

4. Śpiewak R. Ocena skuteczności zabiegów w estetologii medycznej i kosmetologii: Jak zmierzyć obiektywnie wrażenia subiektywne? Acad Aesthet Anti-Aging Med. 2013;4:3-12.

5. Kamińska A, Jabłońska K, Drobnik A, ed. Praktyczna kosmetologia krok po kroku. Kosmetologia twarzy. Warszawa: Wyd. PZWL; 2017.

6. Hasan I, Kumar P, Ahmad H, Mesotherapy Strategies and Techniques: A View. Journal of Pharma and Ayurved Research. 2020;1(1):46-56.

7. Tysiac-Miśta M, Brzoza K, Burek K, et al. Substancje stosowane w mezoterapii igłowej. Kosmetologia Estetyczna. 2019;1(8):97-103.

8. Kabacińska Ż, Urtnowska-Joppek K. Dwutlenek węgla w kosmetologii. Efekty oraz kryteria doboru urządzeń do karboksyterapii. Kos metologia Estetyczna. 2020;5(9):385-388.

9. Gemza K, Surgiel-Gemza A. Wielokierunkowe działanie zabiegu karboksyterapii w walce z mechanizmami wywołującymi cellulit. Kosmetologia Estetyczna. 2018;3(7):317-322.

10. Kołodziejczak A. Kriolipoliza. In: Kołodziejczak A. ed. Kosmetologia 1. Warszawa: Wyd. PZWL; 2019:477-481.

11. Bagińska I. Gorące ultradźwięki. Technologia HIFU. Kosmetologia Es tetyczna. 2017;3(6):291-292.

12.Walkiewicz-Cyrańska B. PLEXR Mechanizm działania mikrowiązki plazmy. Derma News. 2016;58:12-14.
13. Sekita-Pilch M. Wpływ zabiegu plazmy na redukcję zmarszczek poziomych czoła. Opis przypadku. Kosmetologia Estetyczna. 2017;4(6):393-396 14. Obtułowicz K, ed. Alergologia. Warszawa: Wyd. PZWL; 2017.

15. Bolechowski F. Podstawy ogólnej diagnostyki klinicznej. Warszawa: Wyd. PZWL; 1982:183-193.

16. Groniowski J, Kruś S, Chibowski D. Podstawy patomorfologii: podręcznik dla studentów medycyny. Warszawa: Wyd. PZWL; 1991:239-240.

17. Mamcarz B, Prandecka D, eds. Medycyna estetyczna w praktyce. Tom 1. Warszawa: Oficyna Wydawnicza Medical Education; 2010.

18. Goisis M, ed. Injections in Aesthetic Medicine. Atlas of Full-face and Fullbody Treatment. Warszawa: Polish edition by Medipage; 2018.

19. Rubin MG, ed. Dermatologia kosmetyczna:Pilingi chemiczne. Wrocław: Elsevier Urban \& Partner; 2008.

20. Sadowska A, Kamm A. Sposoby zapobiegania i niwelowania hiperpigmentacji skóry twarzy w gabinecie kosmetologicznym. Ocena aktualnego stanu wiedzy społeczeństwa. Aesth Cosmetol Med. 2020;9(4):363-382.

21. Kołodziejczak A. Blizny i gojenie się skóry. In: Kołodziejczak A, ed. Kosmetologia 1. Warszawa: Wyd. PZWL; 2019:203-214.

22. Klonowska J. Epidermoliza jako powikłanie po peelingu 45\% kwasem pirogronowym. Opis przypadku. Kosmetologia Estetyczna. 2018;4(7): 383-387.

23. Alam M, Gladstone HB, Tung RC, eds. Requisites in Dermatology: Cosmetic Dermatology. Wrocław: Polish edition by Elsevier Urban \& Partner; 2011.

24. Walkowicz G. Peelingi chemiczne - nowe protokoły zabiegowe i możliwe powikłania. Kosmetologia Estetyczna. 2019;5(8):567-570.

25. Noszczyk M, ed. Kosmetologia pielegnacyjna i lekarska. Warszawa: Wyd. PZWL; 2016.

26. Plachouri K-M, Georgiou S. Mesotherapy: Safety profile and management of complications. Journal of Cosmetic Dermatology. 2019;18(6): 1601-1605

27. Knoll B. Ilustrated Atlas of Esthetic Mesotherapy. Warszawa: Polish edition by Quintessence Publishing Polska; 2017.

28. Ruprich M. Zastosowanie karboksyterapii w redukcji tkanki tłuszczowej oraz niwelowania rozstępów. Kosmetologia Estetyczna. 2018;2(7):189-193.

29.Przylipiak A, ed. Medycyna estetyczna. Podręcznik dla studentów kosmetologii. Warszawa: Wyd. PZWL; 2017.

30. Azuelos A, SidAhmed-Mezi M, La Padula S, et al. High Intensity Focused Ultrasound: A Satisfactory Noninvasive Procedure for Neck Rejuvenation. Aesthetic Surgery Journal. 2019;8(39):NP343-NP351.

31. Sekita-Pilch M. Zastosowanie technologii plazmy w blefaroplastyce. Kosmetologia Estetyczna. 2018;1(7):99-103. 